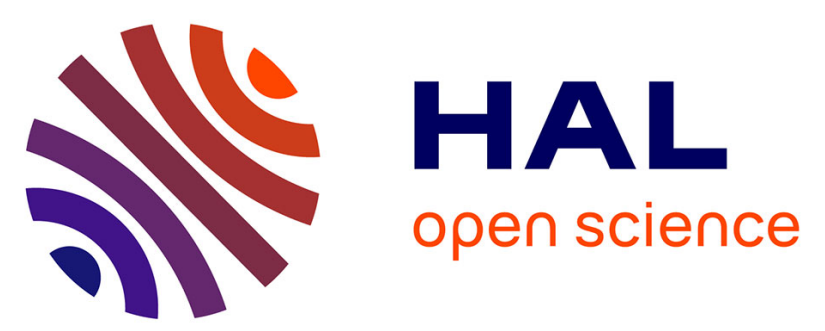

\title{
Reaction of copper(II) with \\ 1-carboxamide-3,5-dimethylpyrazole, 1-carboxamidine-3,5-dimethylpyrazole, 4-acetyl-3-amino-5-methylpyrazole and 5-amino-4-carboxamide-1-phenylpyrazole
}

K. Meszaros Szecsenyi, V.M. Leovac, V.I. Češljević, A. Kovács, G. Pokol, Gy. Argay, A. Kálmán, Goran A. Bogdanović, Ž.K. Jaćimović, Anne Spasojevic de Biré

\section{To cite this version:}

K. Meszaros Szecsenyi, V.M. Leovac, V.I. Češljević, A. Kovács, G. Pokol, et al.. Reaction of copper(II) with 1-carboxamide-3,5-dimethylpyrazole, 1-carboxamidine-3,5-dimethylpyrazole, 4-acetyl-3-amino-5methylpyrazole and 5-amino-4-carboxamide-1-phenylpyrazole. Inorganica Chimica Acta, 2003, 353, pp.253-262. 10.1016/S0020-1693(03)00231-7 . hal-02296125

\section{HAL Id: hal-02296125 \\ https://hal.science/hal-02296125}

Submitted on 30 Sep 2020

HAL is a multi-disciplinary open access archive for the deposit and dissemination of scientific research documents, whether they are published or not. The documents may come from teaching and research institutions in France or abroad, or from public or private research centers.
L'archive ouverte pluridisciplinaire HAL, est destinée au dépôt et à la diffusion de documents scientifiques de niveau recherche, publiés ou non, émanant des établissements d'enseignement et de recherche français ou étrangers, des laboratoires publics ou privés. 


\title{
Reaction of copper(II) with 1-carboxamide-3,5-dimethylpyrazole, 1 carboxamidine-3,5-dimethylpyrazole, 4-acetyl-3-amino-5- methylpyrazole and 5-amino-4-carboxamide-1-phenylpyrazole
}

\author{
K. Me'sza'ros Sze'cse'nyi a,*, V.M. Leovac a, V.I. C`es`ljevic' a , A. Kova'cs ${ }^{\text {b }}$, G. Pokol ${ }^{\text {c }}$, \\ Gy. Argay d, A. Ka'lma’n d, G.A. Bogdanovic' e , Z`.K. Jac'imovic' f , A. Spasojevic'-de Bire' g \\ Department of Chemistry, University of Novi Sad, Faculty of Sciences, 21000 Novi Sad, Trg D. Obradovic'a 3, Serbia and Montenegro \\ b Research Group of Technical Analytical Chemistry of the Hungarian Academy of Sciences at the Institute of General and Analytical Chemistry, \\ Budapest University of Technology and Economics, H-1521 Budapest, Hungary \\ Institute of General and Analytical Chemistry, Budapest University of Technology and Economics, H-1521 Budapest, Hungary \\ d Institute of Chemistry, Chemical Research Center, Hungarian Academy of Sciences, P.O. Box 17, H-1525 Budapest, Hungary \\ e Laboratory of Theoretical Physics and Condensed Matter Physics, VINC ${ }^{` A}$ Institute of Nuclear Sciences, P.O. Box 522, 11001 Belgrade, \\ Serbia and Montenegro \\ Faculty of Metallurgy and Technology, University of Montenegro Podgorica, Serbia and Montenegro
}

Laboratoire de Structures, Properie'te's et Mode'lisation des Solides (SPMS), UMR 8580 du CNRS, Ecole Centrale Paris, Grande Voie des Vignes, 92295 Chaatenay-Malabry Cedex, France

Received 19 December 2002; accepted 28 February 2003

\begin{abstract}
Complex formation of copper(II) bromide and acetate with 1-carboxamide-3,5-dimethylpyrazole (HL ${ }^{3}$ ) and copper(II) bromide with 5amino-4-carboxamide-1-phenylpyrazole $\left(\mathrm{L}^{2}\right)$, 4-acetyl-3-amino-5-methylpyrazole $\left(\mathrm{HL}^{4}\right)$ and 1-carboxamidine-3,5-dimethylpyrazole $\left(\mathrm{HL}^{5}\right)$, was studied. The obtained compounds, $\mathrm{CuBr}_{2}\left(\mathrm{~L}^{2}\right)_{2}, \mathrm{Cu}\left(\mathrm{L}^{3}\right)_{2}, \mathrm{CuBr}_{2}\left(\mathrm{HL}^{4}\right)_{2}, \mathrm{CuBr}_{2}\left(\mathrm{HL}^{5}\right)_{2}$ and $\left[\mathrm{CuBr}\left(\mathrm{HL}^{1}\right)\left(\mathrm{L}^{3}\right)\right]_{2}\left(\mathrm{HL}^{1} \mathrm{denotes}\right.$ the 3,5dimethylpyrazole), are characterized by elemental analysis, FT-IR spectrometry, molar conductivity, TG-MS and DSC. The X-ray structure of $\left[\mathrm{CuBr}\left(\mathrm{HL}^{1}\right)\left(\mathrm{L}^{3}\right)\right]_{2}$ and $\mathrm{Cu}\left(\mathrm{L}^{3}\right)_{2}$ is discussed. For $\left[\mathrm{CuBr}\left(\mathrm{HL}^{1}\right)\left(\mathrm{L}^{3}\right)\right]_{2}$ a dimeric penta-co-ordinated structure has been found; the co-ordination around the metal in $\mathrm{Cu}\left(\mathrm{L}^{3}\right)_{2}$ is trans-square planar. $\mathrm{To}_{\mathrm{CuBr}}\left(\mathrm{L}^{2}\right)_{2}$ and $\mathrm{CuBr}_{2}\left(\mathrm{HL}^{4}\right)_{2}$ a nearly tetrahedral, while for $\mathrm{CuBr}_{2}\left(\mathrm{HL}^{5}\right)_{2}$ an octahedral geometry may be assumed. It means that the geometry of the compounds in the first place depends on the ligand substituents. The course of the complex formation reaction is anion-dependent and may be explained on the basis of Pearson's theory, taking into account the steric factors. A low stability intermediate formation was observed in the thermal decomposition of $\mathrm{Cu}\left(\mathrm{L}^{3}\right)_{2}$. \# 2003 Elsevier B.V. All rights reserved.
\end{abstract}

Keywords: Pyrazole-complexes; Copper(II)-complexes; Pearson theory

\section{Introduction}

Complexes with pyrazole-based ligands are a frequent subject of chemical investigations giving an opportunity for a better understanding the relationship between the

This paper is Part 14 in the series of our studies on Transition Metal Complexe with pyrazole-based ligands. Part 13 [1].

* Corresponding author. Tel.: 381-21-35-0122x832; fax: 381-2154-065. structure and the activity of the active site of metalloproteins. Namely, the metal ion in biological systems is often co-ordinated to one or more imidazole groups which are part of histidine fragments of the proteins [2]. On the other hand, the aromatic ring systems of imidazoles and pyrazoles are very much alike in the electronic and steric sense, but the latter ones more readily synthesized compared to the former ligands. Hence, there are excellent review articles on the pyrazole-based coordination compounds [35]. Nowadays, attention is paid to the design of various pyrazole ligands with special structural properties to fulfill the 
E-mail address: mszk@eunet.yu (K. Me'sza'ros Sze'cse'nyi).

specific stereochemical requirements of a particular metal-binding site [6]. The review [6] deals with the coordination chemistry of transition metal complexes with bi- and polydentate pyrazole derivatives.

In our systematic studies on transition metal complexes the pyrazole derivatives take part in co-ordination mostly as monodentate ligands [79]. However, during thermal treatment of the compounds, depending on the pyrazole substituents, relatively stable intermediates with a stoichiometric composition are formed, whereby the co-ordination mode of the ligand changes. This points to a possibility of a solid phase synthesis of new compounds. The goal of our systematic studies on pyrazole complexes with transition metal ions is to examine how the substituents of the pyrazole ring, as well as various cations and anions, influence the course of the complex formation reaction. Additionally, our aim is to gain information on the structural dependence of the thermal properties within the investigated series.

In this part we report the synthesis, physico-chemical characteristics and structure of copper(II) complexes formed with 5amino-4-carboxamide-1-phenylpyrazole, $\quad\left(\mathrm{L}^{2}\right), \quad$ 1-carboxamide-3,5-dimethylpyrazole, $\quad\left(\mathrm{HL}^{3}\right), \quad$ 4-acetyl-3-amino-5methylpyrazole $\left(\mathrm{HL}^{4}\right)$ and 1-carboxamidine-3,5-dimethylpyrazole, $\left(\mathrm{HL}^{5}\right)$ ligands. Compounds with the following compositions are obtained:

$\mathrm{CuBr}_{2}\left(\mathrm{~L}^{2}\right)_{2}, \mathrm{Cu}\left(\mathrm{L}^{3}\right)_{2}, \mathrm{CuBr}_{2}\left(\mathrm{HL}^{4}\right)_{2}, \mathrm{CuBr}_{2}\left(\mathrm{HL}^{5}\right)_{2}$ and $\left[\mathrm{CuBr}_{(}\left(\mathrm{HL}^{1}\right)\left(\mathrm{L}^{3}\right)\right]_{2}$, where $\mathrm{HL}^{1}$ denotes the 3,5-dimethylpyrazole ligand.

\section{Experimental}

\subsection{General procedures}

All pyrazole derivatives were reagent grade, commercial products of Aldrich Company, except of $\mathrm{HL}^{4}$. Its synthesis was described previously [10]. The copper(II) salts were analytical reagent grade. The IR-spectra were recorded in the range of $4000150 \mathrm{~cm}^{1}$ on a Perkin Elmer System 2000 FT-IR spectrometer at room temperature using $\mathrm{KBr}$ pellets in the mid-IR range and polyethylene pellets in the far-IR range. The spectra were obtained with a resolution of $4 \mathrm{~cm}^{1}$ and with a co-addition of 16 scans. The thermal analysis was carried out using a DuPont 2000 TA system with a thermobalance DuPont 951 TGA. At the thermogravimetric measurements the samples were heated in a platinum crucible with a heating rate of $10 \mathrm{~K} \mathrm{~min}{ }^{1}$ up to 1000 $\mathrm{K}$. With the same heating rate the DSC curves were registered up to $600 \mathrm{~K}$ using an open aluminium pan as sample holder and an empty aluminium pan as reference. For the TG-MS measurements a TA Instruments SDT 2960 was employed, coupled with Balzers Termostar GSD $300 \mathrm{~T}$ capillary MS. The molar conductivity of freshly prepared $10^{3} \mathrm{~mol} \mathrm{dm}^{3}$ solutions of the compounds in DMF was measured at room temperature using a Jenway 4010 conductivity meter. Magnetic susceptibility measurements were conducted at room temperature by means of a magnetic susceptibility balance MSB-MKI, Sherwood Scientific Ltd, Cambridge. The data were corrected for diamagnetic susceptibilities.

\subsection{Synthesis}

All the compounds were synthesized by mixing warm ethanolic solutions of the ligand ( $2 \mathrm{mmol}$ ) and copper(II) bromide (1 mmol) except for $\mathrm{Cu}\left(\mathrm{L}^{3}\right)_{2}$, where copper(II) acetate monohydrate was used instead, and both the ligand (2 mmol) and the metal salt $(1 \mathrm{mmol})$ were dissolved in methanol. The total volume of the mixture was about $10 \mathrm{~cm}^{3}$. The coloured precipitates were obtained at room temperature. The formed compounds were washed with cold $\mathrm{EtOH}$ and $\mathrm{Et}_{2} \mathrm{O}$ and dried at room temperature.

\subsection{1. $\left[\mathrm{CuBr}\left(\mathrm{HL}^{1}\right)\left(\mathrm{L}^{3}\right)\right]_{2}$}

Reaction time: 24 h. Colour: green. Yield: $64.7 \%$. $\mathrm{m}_{\mathrm{eff}}, \mathrm{m}_{\mathrm{B}}: 1.72 . \mathrm{l}_{\mathrm{M}}, \mathrm{S} \mathrm{cm} \mathrm{mol}^{1}: 31.5$. Elemental analysis data (Found (Required)\%): C, 33.10 (34.98); H, 3.94 (4.27); N, 18.80 (18.54). 


\subsection{2. $\mathrm{CuBr}_{2}\left(\mathrm{~L}^{2}\right)_{2}$}

Reaction time: 0.5 h. Colour: black. Yield: $74.2 \%$. $\mathrm{m}_{\text {eff, }} \mathrm{m}_{\mathrm{B}}: 2.19 . \mathrm{l}_{\mathrm{M}}, \mathrm{S} \mathrm{cm}^{2} \mathrm{~mol}^{1}: 55.0$. Elemental analysis data (Found (Required)\%): C, 38.60 (38.26); H, 3.78 (3.21); N, 18.22 (17.85).

\subsection{3. $\mathrm{Cu}\left(\mathrm{L}^{3}\right)_{2}$}

Reaction time: 3 h. Colour: blue. Yield: $76.5 \%$. meff, $\mathrm{mB}_{\mathrm{B}}$ : 1.80. $1 \mathrm{M}, \mathrm{S} \mathrm{cm}^{2} \mathrm{~mol}^{1}$ : 14.6. Elemental analysis data (Found (Required)\%): C, 42.62 (42.40); H, 5.21 (4.75); N, 24.50 (24.73).

\subsection{4. $\mathrm{CuBr}_{2}\left(\mathrm{HL}^{4}\right)_{2}$}

Reaction time: 15 h. Colour: black. Yield: $83.3 \% . \mathrm{m}_{\mathrm{eff}}, \mathrm{m}_{\mathrm{B}}: 1.85 . \mathrm{l}_{\mathrm{M}}, \mathrm{S} \mathrm{cm} \mathrm{mol}^{1}$ : 48.4. Elemental analysis data (Found (Required)\%): C, 28.67 (28.73); H, 3.77 (3. 62); N, 16.90 (16.75).

\subsection{5. $\mathrm{CuBr}_{2}\left(\mathrm{HL}^{4}\right)_{2}$}

Reaction time: 24 h. Colour: blue. Yield: $75.0 \%$. meff, $\mathrm{mB}_{\mathrm{B}}$ : 1.83. $\mathrm{l}_{\mathrm{M}}, \mathrm{S} \mathrm{cm} \mathrm{mol}^{1}$ : 95.1. Elemental analysis data (Found (Required)\%): C, 29.31 (28.84); H, 3.79 (4.03); N, 23.38 (22.73).

All the compounds were characterized by FT-IR spectrometry. Compounds $\left[\mathrm{CuBr}\left(\mathrm{HL}^{1}\right)\left(\mathrm{L}^{3}\right)\right]_{2}$ and $\mathrm{Cu}\left(\mathrm{L}^{3}\right)_{2}$ were also studied by single crystal X-ray structure analysis. The structure of the compounds is presented in ORTEP projection [11]. For the compounds

Table 1

IR assignments

\begin{tabular}{|c|c|c|c|}
\hline $\mathrm{CuBr}_{2}\left(\mathrm{~L}^{2}\right)$ & $\mathrm{CuBr}_{2}\left(\mathrm{HL}^{4}\right)_{2}$ & $\mathrm{CuBr}_{2}\left(\mathrm{HL}^{5}\right)_{2}$ & Assignment \\
\hline & $3439 \mathrm{~s}$ & $3312 \mathrm{~s}$ & NH stretch \\
\hline & $3305 \mathrm{~s}^{\mathrm{a}}$ & & NH stretch \\
\hline \multirow[t]{2}{*}{$3427 \mathrm{~s}$} & $3146 \mathrm{~s}$ & $3262 \mathrm{sh}$ & $\mathrm{NH}_{2}$ asymmetric stretch \\
\hline & $2962 \mathrm{~m}^{\mathrm{a}}$ & & $\mathrm{NH}_{2}$ asymmetric stretch \\
\hline \multirow[t]{2}{*}{$3341 \mathrm{~s}$} & $3050 \mathrm{~s}$ & $3104 \mathrm{~s}$ & $\mathrm{NH}_{2}$ symmetric stretch \\
\hline & $2852 \mathrm{~m}^{\mathrm{a}}$ & & $\mathrm{NH}_{2}$ symmetric stretch \\
\hline $3090 \mathrm{vw}$ & & & aryl $\mathrm{CH}$ stretch \\
\hline $3067 \mathrm{vw}$ & & & aryl CH stretch \\
\hline $3050 \mathrm{vw}$ & & & aryl CH stretch \\
\hline $2967 \mathrm{vw}$ & & & $\mathrm{CH}_{3}$ asymmetric stretch \\
\hline \multirow[t]{2}{*}{$2931 \mathrm{vW}$} & & $2924 \mathrm{vw}$ & $\mathrm{CH}_{3}$ symmetric stretch \\
\hline & & $1665 \mathrm{vs}$ & imine $\mathrm{CN}$ stretch \\
\hline 1648 vs & 1623 vs & & CO stretch \\
\hline 1625 vs & & & pyr skeleton stretch $\mathrm{CN}$ stretch \\
\hline $1610 \mathrm{sh}$ & & & aryl skeleton stretch \\
\hline $1596 \mathrm{sh}$ & $1563 \mathrm{w}$ & $1591 \mathrm{~m}$ & pyr skeleton stretch ( $\mathrm{NH}_{2}$ scissoring $)^{b}$ \\
\hline $1587 \mathrm{sh}$ & & & aryl skeleton stretch \\
\hline $1552 \mathrm{~s}$ & $1536 \mathrm{~s}$ & $1565 \mathrm{~m}$ & pyr skeleton stretch $\left(\mathrm{NH}_{2} \text { scissoring }\right)^{b}$ \\
\hline
\end{tabular}


$1516 \mathrm{w}$

$1497 \mathrm{~m}$

$1458 \mathrm{~m}$

$1441 \mathrm{~s}$

$1450 \mathrm{~m}$

$1414 \mathrm{w}$

$1386 \mathrm{~m}$

$1372 \mathrm{sh}$

$1353 \mathrm{~m}$

$1320 \mathrm{~s}$

$1315 \mathrm{w}$

$1296 \mathrm{~m}$

$1287 \mathrm{~m}$

$1230 \mathrm{~m}$

$1175 \mathrm{w}$

$1131 \mathrm{w}$

$1092 \mathrm{w}$

$1077 \mathrm{w}$

$1046 \mathrm{w}$

$1019 \mathrm{w}$

$962 \mathrm{~m}$

$916 \mathrm{~m}$

$801 \mathrm{~m}$

$777 \mathrm{~m}$

$754 \mathrm{~m}$

$734 \mathrm{~m}$

$697 \mathrm{~m}$

$664 \mathrm{w}$

$631 \mathrm{w}$

$591 \mathrm{w}$

$680 \mathrm{~m}$

$1147 \mathrm{~m}$

$1095 \mathrm{~m}$

$1071 \mathrm{w}$

$1037 \mathrm{w}$

$1025 \mathrm{w}$

$960 \mathrm{~m}$

994 m

$843 \mathrm{~m}$

$806 \mathrm{w}$

$1134 \mathrm{~m}$

$1078 \mathrm{w}$

$1058 \mathrm{~m}$

$1030 \mathrm{w}$

$249 \mathrm{~m}$

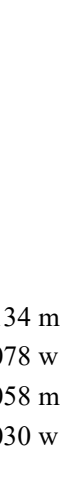

$742 \mathrm{~m}$

$769 \mathrm{~m}$

$714 \mathrm{w}$

$665 \mathrm{w}$

$648 \mathrm{w}$

$592 \mathrm{~m}$

$583 \mathrm{sh}$

$562 \mathrm{w}$ aryl skeleton stretch

$\mathrm{CH}_{3}$ asymmetric def pyr skeleton stretch

$\mathrm{CH}_{3}$ asymmetric def

aryl skeleton stretch

$\mathrm{CH}_{3}$ asymmetric def

$\mathrm{CH}_{3}$ asymmetric def pyr skeleton stretch

$\mathrm{CH}_{3}$ symmetric def pyr skeleton stretch

$\mathrm{CH}_{3}$ symmetric def pyr skeleton stretch

$\mathrm{CH}_{3}$ symmetric def

$\mathrm{NH}$ bend pyr skeleton stretch

pyr skeleton stretch def

$\mathrm{CN}$ stretch

aryl in-plane $\mathrm{CH}$ bend

aryl in-plane $\mathrm{CH}$ bend

aryl in-plane $\mathrm{CH}$ bend

aryl in-plane $\mathrm{CH}$ bend

pyr skeleton stretch

CC stretch pyr skeleton def

$\mathrm{NH}_{2}$ rock pyr skeleton stretch

$\mathrm{CH}_{3}$ rock

pyr skeleton stretch $\mathrm{NH}_{2}$ rock

$\mathrm{CC}$ stretch $\mathrm{CH}_{3}$ rock

aryl $\mathrm{CH}$ wag

imine NH wag

pyr skeleton defCN stretch

aryl $\mathrm{CH}$ wag

$\mathrm{CNH}_{2}$ bend pyr skeleton torsion

aryl skeleton bend

aryl $\mathrm{CH}$ wag

NCN bend

$\mathrm{CC}$ stretch $\mathrm{CCH}_{3}$ bend

pyr skeleton torsion

$\mathrm{CO}$ wag $\mathrm{CH}_{3}$ rock

pyr skeleton defCC stretch

$\mathrm{NH}_{2}$ torsion $\mathrm{NH}_{2}$ wag 


\begin{tabular}{|c|c|c|c|}
\hline $537 \mathrm{w}$ & & & aryl ring torsion \\
\hline \multirow[t]{2}{*}{$500 \mathrm{~m}$} & $451 \mathrm{~s}$ & $516 \mathrm{~s}$ & $\mathrm{NH}_{2}$ wag $\mathrm{NH}_{2}$ torsion \\
\hline & $470 \mathrm{~s}$ & & $\mathrm{NH}$ wag $\mathrm{CCH}_{3}$ wag \\
\hline $423 \mathrm{w}$ & $367 \mathrm{w}$ & $408 \mathrm{w}$ & $\mathrm{CuBr}$ stretch \\
\hline \multirow[t]{2}{*}{$369 w$} & $323 \mathrm{~m}$ & $343 \mathrm{~m}$ & pyr skeleton torsion \\
\hline & & $313 \mathrm{w}$ & $\mathrm{CCH}_{3}$ wag $\mathrm{CNH}_{2}$ wag \\
\hline $251 \mathrm{w}$ & $245 \mathrm{w}$ & $285 \mathrm{w}$ & $\mathrm{CuN}$ stretch \\
\hline $212 \mathrm{w}$ & & $210 \mathrm{w}$ & $\mathrm{CH}_{3}$ torsion \\
\hline
\end{tabular}

${ }^{\mathrm{a}}$ Observed also in the IR spectrum of the ligand [12]; may be attributed to different pattern of intermolecular interactions in the crystal. $\mathrm{b} \mathrm{NH}_{2}$ scissoring may contribute to these fundamentals in derivatives with an $\mathrm{NH}_{2}$ group. with no X-ray data the IR assignments [12 14] are given in Table 1.

\subsection{Crystal structure determination}

Crystal data for $\left[\mathrm{CuBr}\left(\mathrm{HL}^{1}\right)\left(\mathrm{L}^{3}\right)\right]_{2}$ and $\mathrm{Cu}\left(\mathrm{L}^{3}\right)_{2}$ were collected at room temperature on Enraf-Nonius CAD-4 diffractometers [15] in different laboratories (Paris, Budapest), using Mo Ka radiation (10.71073 $\mathrm{A}^{\circ}$ ) and v/2u scans. Data correction [16] and absorption correction was applied: psi-scan type [17] for $\mathrm{Cu}\left(\mathrm{L}^{3}\right)_{2}$ and Gaussian-type [18], based on the crystal morphology $\left(\mathrm{T}_{\min } 0.335, \mathrm{~T}_{\max } 0.735\right)$ for $\left[\mathrm{CuBr}\left(\mathrm{HL}^{1}\right)\left(\mathrm{L}^{3}\right)\right]_{2}$.

The structures were solved by heavy atom [19] and difference Fourier methods and refined on $\mathrm{F}^{2}$ by fullmatrix least-squares method [20]. The weighting schemes were w $1 /\left[\mathrm{s}^{2}\left(\mathrm{~F}_{\mathrm{o}}^{2}\right)(0.1731 \mathrm{P})^{2}\right]$ and $\mathrm{w} 1 /\left[\mathrm{s}^{2}\left(\mathrm{~F}_{\mathrm{o}}^{2}\right)(0.1000 \mathrm{P})^{2}\right]$ for $\left.\left[\mathrm{CuBr}^{2}(\mathrm{HL})^{1}\right)\left(\mathrm{L}^{3}\right)\right]_{2}$ and $\mathrm{Cu}\left(\mathrm{L}^{3}\right)$, respectively; $\mathrm{P}\left(\mathrm{F}_{\mathrm{o}}{ }^{2} 2 \mathrm{~F}_{\mathrm{c}}{ }^{2}\right) / 3$. In both crystal structures non-hydrogen atoms were refined with anisotropic displacement parameters. In refinement of $\mathrm{Cu}\left(\mathrm{L}^{3}\right)_{2}$ some least-squares restraints (ISOR, DELU for all non-hydrogen atoms, DFIX and SADI for $\mathrm{NH}$ distances) were used. $\mathrm{H}$ atoms (except $\mathrm{H} 7$ and $\mathrm{H} 17$ in $\mathrm{Cu}\left(\mathrm{L}^{3}\right)_{2}$, they were located in difference map) were placed in calculated positions and refined with isotropic displacement parameters. In the case of

$\left[\mathrm{CuBr}\left(\mathrm{HL}^{1}\right)\left(\mathrm{L}^{3}\right)\right]_{2}$ all $\mathrm{H}$ atoms were placed in calculated positions (for the purpose of decreasing the number of refined parameters) and they are in good agreement with positions located in difference maps. Details and final $\mathrm{R}$ values are given in Table 2, together with other experimental data relevant to the X-ray analyses. Note: unit cell dimensions for $\left[\mathrm{CuBr}\left(\mathrm{HL}^{1}\right)\left(\mathrm{L}^{3}\right)\right]_{2}$ can be transformed to the next values: a $8.965 \mathrm{~A}^{\circ}, \mathrm{b} 9.277 \mathrm{~A}^{\circ}, \mathrm{c} 10.734 \mathrm{~A}^{\circ}$, a 73.478, b 71.678, g61.188.

\section{Results and discussion}

The complexes are coloured and stable in air. They are soluble in DMF and $\mathrm{MeOH}$, slightly soluble in EtOH, but insoluble in $\mathrm{H}_{2} \mathrm{O}$ and $\mathrm{Et}_{2} \mathrm{O}$. The molar conductivity for all of the compounds was measured in DMF. A low molar conductivity is characteristic for the $\mathrm{Cu}\left(\mathrm{L}^{3}\right)_{2}$ referring to its non-electrolytic character, while in the case of the $\mathrm{CuBr}_{2}\left(\mathrm{HL}^{5}\right)_{2}$ the value of the molar conductivity corresponds to an electrolyte of 1:1 type [21]. The molar conductivity of the other complexes suggests only a partial replacement of the bromide ion by the solvent molecule:

$\mathrm{CuBr}_{2}(\mathrm{~L})_{2} \mathrm{DMFXCuBr}(\mathrm{L})_{2} \mathrm{DMFBr}$

Table 2

Crystal data and structure refinement for $\left[\mathrm{CuBr}\left(\mathrm{HL}^{1}\right)\left(\mathrm{L}^{3}\right)\right]_{2}$ and $\mathrm{Cu}\left(\mathrm{L}^{3}\right)_{2}$

\begin{tabular}{|c|c|c|}
\hline & {$\left[\mathrm{CuBr}\left(\mathrm{HL}^{1}\right)\left(\mathrm{L}^{3}\right)\right]_{2}$} & $\mathrm{Cu}\left(\mathrm{L}^{3}\right)_{2}$ \\
\hline $\begin{array}{l}\text { Empirical formu- } \\
\text { la }\end{array}$ & $\mathrm{C}_{22} \mathrm{H}_{32} \mathrm{Br}_{2} \mathrm{Cu}_{2} \mathrm{~N}_{10} \mathrm{O}_{2}$ & $\mathrm{C}_{12} \mathrm{H}_{16} \mathrm{CuN}_{6} \mathrm{O}_{2}$ \\
\hline Formula mass & 755.5 & 339.85 \\
\hline Temperature $(\mathrm{K})$ & 293(2) & 293(2) \\
\hline Wavelength $\left(\mathrm{A}^{\circ}\right)$ & 0.710730 & 0.710730 \\
\hline Crystal system & triclinic & triclinic \\
\hline Space group & $\mathrm{P}^{-}$ & $\mathrm{P}^{-}$ \\
\hline
\end{tabular}




\begin{tabular}{|c|c|c|}
\hline \multicolumn{3}{|l|}{$\begin{array}{l}\text { Unit cell } \\
\text { dimensions a }\left(\mathrm{A}^{\circ}\right.\end{array}$} \\
\hline ) & $9.277(4)$ & $8.461(1)$ \\
\hline $\mathrm{b}\left(\mathrm{A}^{\circ}\right)$ & $9.287(5)$ & $8.631(1)$ \\
\hline $\mathrm{c}\left(\mathrm{A}^{\circ}\right)$ & $10.734(5)$ & $10.745(2)$ \\
\hline $\mathrm{a}(8)$ & $91.11(4)$ & $68.72(1)$ \\
\hline $\mathrm{b}(8)$ & $106.53(4)$ & $70.29(1)$ \\
\hline $\mathrm{g}(8)$ & $122.25(4)$ & $77.64(1)$ \\
\hline Volume $\left(\mathrm{A}^{\circ 3}\right)$ & $732.9(6)$ & $684.57(17)$ \\
\hline Z & 1 & 2 \\
\hline $\begin{array}{l}\text { Density (calculated) } \\
\left(\mathrm{Mg} \mathrm{m}^{3}\right)\end{array}$ & 1.712 & 1.649 \\
\hline $\begin{array}{l}\text { Absorption } \\
\text { coefficient }\left(\mathrm{mm}^{1}\right)\end{array}$ & 4.215 & 1.610 \\
\hline $\mathrm{F}\left(\begin{array}{lll}0 & 0 & 0\end{array}\right)$ & 378 & 350 \\
\hline Crystal size $(\mathrm{mm}) 0$. & .250 .210 .08 & 0.500 .250 .20 \\
\hline $\begin{array}{l}\text { u range for data } \\
\text { collection }(8)\end{array}$ & 2.025 u5 27.99 & 2.555 u 538.47 \\
\hline Index ranges & $\begin{array}{l}125 \mathrm{~h} 511 ; 125 \text { k } 512 \text {; } \\
051514\end{array}$ & $\begin{array}{l}145 \text { h } 513 ; 155 \text { k } 514 \\
185158\end{array}$ \\
\hline $\begin{array}{l}\text { Reflections } \\
\text { collected }\end{array}$ & 3723 & 8193 \\
\hline $\begin{array}{l}\text { Independent } \\
\text { reflections }\end{array}$ & $3533\left[\mathrm{R}_{\text {int }} 0.0235\right]$ & $7666\left[\mathrm{R}_{\text {int }} 0.0137\right]$ \\
\hline Refinement method & $\begin{array}{l}\text { Full-matrix least-squares } \\
\text { on } \mathrm{F}^{2}\end{array}$ & $\begin{array}{l}\text { Full-matrix } \\
\text { leastsquares on } \mathrm{F}^{2}\end{array}$ \\
\hline $\begin{array}{l}\text { Data/restraints/ } \\
\text { parameters }\end{array}$ & $3533 / 0 / 172$ & $7666 / 193 / 196$ \\
\hline $\begin{array}{l}\text { Goodness-of-fit on } \\
\mathrm{F}^{2}\end{array}$ & 1.031 & 0.907 \\
\hline $\begin{array}{l}\text { Final } R \text { indices } \\
{[\mathrm{I} 2 \mathrm{~s}(\mathrm{I})]}\end{array}$ & $\begin{array}{l}\mathrm{R}_{1} 0.0869, \mathrm{wR}_{2} \\
0.2247\end{array}$ & $\begin{array}{l}\mathrm{R}_{1} 0.0449, \mathrm{wR}_{2} \\
0.1315\end{array}$ \\
\hline
\end{tabular}

where (L) denotes $\left(\mathrm{L}^{2}\right)$ and $\left(\mathrm{HL}^{4}\right)$. The same is valid for the $\left[\mathrm{CuBr}\left(\mathrm{HL}^{1}\right)\left(\mathrm{L}^{3}\right)\right]_{2}$ complex with mixed ligands. Nonetheless, for these compounds the co-ordination of the anion may be regarded as non-ionic, even in solution.

\subsection{Description of the structures}

\subsection{1. $\left[\mathrm{CuBr}\left(\mathrm{HL}^{1}\right)\left(\mathrm{L}^{3}\right)\right]_{2}$}

The compound has a dimeric centrosymmetric structure (Fig. 1) with a $\mathrm{Cu} C \mathrm{Cu}$ ? distance of $3.72 \mathrm{~A}^{\circ}$. The coordination around the $\mathrm{Cu}$ atom is a square pyramid, formed by co-ordination of the $\mathrm{N} 1$ atom of the

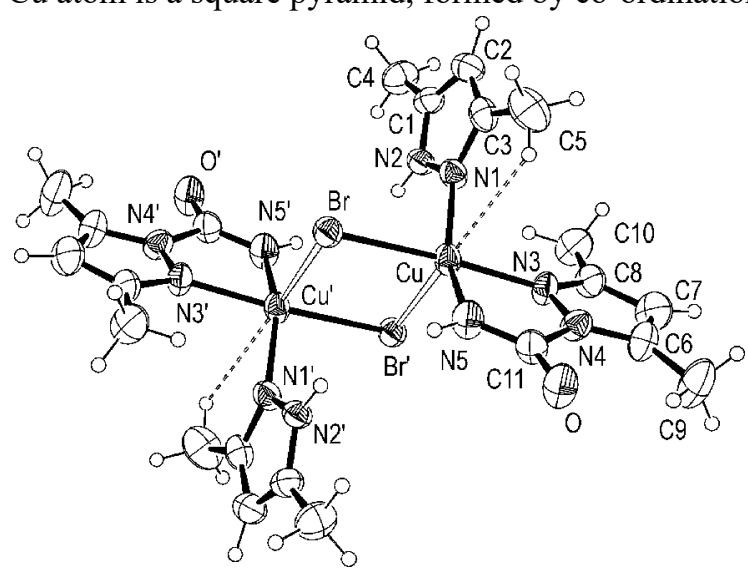

Fig. 1. ORTEP drawing of complex $\left[\mathrm{CuBr}\left(\mathrm{HL}^{1}\right)\left(\mathrm{L}^{3}\right)\right]_{2}$ with atom numbering scheme. 
monodentate $\mathrm{HL}^{1}$ and $\mathrm{N} 3$ and $\mathrm{N} 5$ of the bidentate $\mathrm{L}^{3}$ as well as the bridging bromine atoms* $\mathrm{Br}$ in the equatorial plane and $\mathrm{Br}$ ? in the apical position. As the ligand $\mathrm{L}^{3}$ is approximately planar with $\mathrm{C} 9 \mathrm{H} \mathrm{O}$, an intramolecular hydrogen-bond formation takes place, yielding a six-membered $\mathrm{C} 9 \mathrm{H}$ OC11 N4 C6 ring. The copper atoms are displaced from the equatorial N1 N3 N5 Br coordination plane to the apical $\mathrm{Br}$ ? atom for an expectable value of $0.24 \mathrm{~A}^{\circ}$. However, the arrangement of the atoms in the equatorial plane is quite irregular. Namely, the $\mathrm{N} 3, \mathrm{~N} 5$ and $\mathrm{Br}$ atoms together with the two $\mathrm{Cu}$ atoms are almost ideally coplanar (root-mean-square deviation of $\mathrm{N} 3, \mathrm{~N} 5, \mathrm{Br}, \mathrm{Cu}$ atoms is $0.006 \mathrm{~A}^{\circ}$ ) what is an unusual position for a square-pyramidal coordination. This geometry may be explained by the interaction between the metal atom and the $\mathrm{C} 5$ methyl group's hydrogen that is supported by the short $\mathrm{Cu} \mathrm{H}$ distance $\left(2.67 \mathrm{~A}^{\circ}\right)$. Besides, the $\mathrm{N} 1 \mathrm{C} 3 \mathrm{C} 5$ angle is much smaller than the $\mathrm{C} 2 \mathrm{C} 3 \mathrm{C} 5$ one. It means that the $\mathrm{C} 5$ methyl group is shifted towards $\mathrm{Cu}$. Although the rotation of $\mathrm{HL}^{1}$ around the $\mathrm{CuN} 1$ bond is possible, it is oriented in such a way as to enable the $\mathrm{CuH}$ contact in the $\mathrm{CuN1C3C5}$ plane with a torsion angle of nearly 08 . As a consequence, $\mathrm{N} 1$ is displaced from the $\mathrm{N} 3 \mathrm{~N} 5 \mathrm{BrCu}$ plane for $0.82 \mathrm{~A}^{\circ}$ (Fig. 2), because the whole $\mathrm{HL}^{1}$ is shifted out of the equatorial plane to obtain the best position for the $\mathrm{Cu} \mathrm{H}$ interaction, resulting a pseudo-

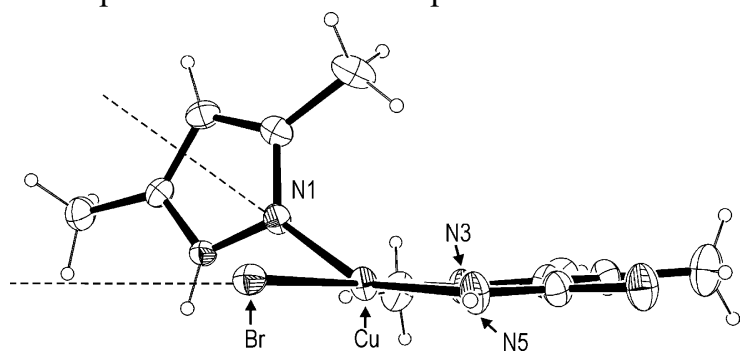

octahedral surrounding around the copper atom. The bridging $\mathrm{Br}$ ? and $\mathrm{H}(\mathrm{Cu})$ atoms are displaced from the $\mathrm{N} 1 \mathrm{~N} 3 \mathrm{~N} 5 \mathrm{Br}$ equatorial plane for 2.98 and $2.24 \mathrm{~A}^{\circ}$, respectively, and to the opposite direction forming a $\mathrm{Br}$ ? $\mathrm{CuH}$ angle of 1538 .

The angle between the mean planes of the two pyrazole rings is 788 . There is a short $\mathrm{HL}^{1} \mathrm{~L}^{3}$ interligand contact of $3.26 \mathrm{~A}^{\circ}$ between the $\mathrm{C} 10$ methyl group and the $\mathrm{N} 1$ atom, enabling a short $\mathrm{CH}$ p interaction between a hydrogen atom of $\mathrm{C} 10$ and the $\mathrm{N} 1 \mathrm{~N} 2$ bond centroid $(\mathrm{Cg})$ with a $\mathrm{H} \mathrm{Cg}$ distance of about $2.6 \mathrm{~A}^{\circ}$.

In the crystal lattice, the binuclear molecules are mutually connected by intermolecular $\mathrm{N} 2 \mathrm{H} \mathrm{O}, \mathrm{N} 5 \mathrm{HO}$ and C4 H O hydrogen bonds forming 3D supramolecular structure. The geometrical parameters of the H-bonds are: $\mathrm{N} 2 \mathrm{H} 2 \mathrm{~N} 0.86 \mathrm{~A}^{\circ}$, $\mathrm{N} 2 \mathrm{O}$ (i) $3.16 \mathrm{~A}^{\circ}, \mathrm{H} 2 \mathrm{~N} \mathrm{O}$ (i) $2.43 \mathrm{~A}^{\circ}, \mathrm{N} 2 \mathrm{H} 2 \mathrm{~N} \mathrm{O}$ (i) 1728 ; $\mathrm{N} 5 \mathrm{H} 5 \mathrm{~N} 0.86 \mathrm{~A}^{\circ}, \mathrm{N} 5 \mathrm{O}$ (ii) $3.01 \mathrm{~A}^{\circ}, \mathrm{H} 5 \mathrm{~N}$ O(ii) $2.16 \mathrm{~A}^{\circ}$, N5H5N O(ii) 1728; C4H4A $0.96 \mathrm{~A}^{\circ}$, C4 O(i) $3.24 \mathrm{~A}^{\circ}, \mathrm{H} 4 \mathrm{~A}$ O(i) $2.36 \mathrm{~A}^{\circ}, \mathrm{C} 4 \mathrm{H} 4 \mathrm{~A}$ O(i) 1518; symmetry code: (i) x 1,y 1, z; (ii) $\mathrm{x} 1, \mathrm{y} 1$, $\mathrm{z}$. The packing diagram for the compound is presented in Fig. 3, while the interatomic bond lengths and selected bond angles in the complex are given in Table 3.

\subsection{2. $\mathrm{Cu}\left(\mathrm{L}^{3}\right)_{2}$}

The a-modification of this compound was synthesized by Valach et al. [22] by the reaction of freshly obtained [Cu(NCO) 2 (2,4-Me 2 py)] with 3,5-dimethylpyrazole ligand in a methanolic solution at $278 \mathrm{~K}$. The crystal structure of this modification was determined by X-ray structure analysis. By similar method, at higher temperature the former authors obtained the b-modification of the same compound also, in form of blue flakes.

In our case, the compound was prepared by the reaction of copper(II) acetate with 1-carboxamide-3,5-

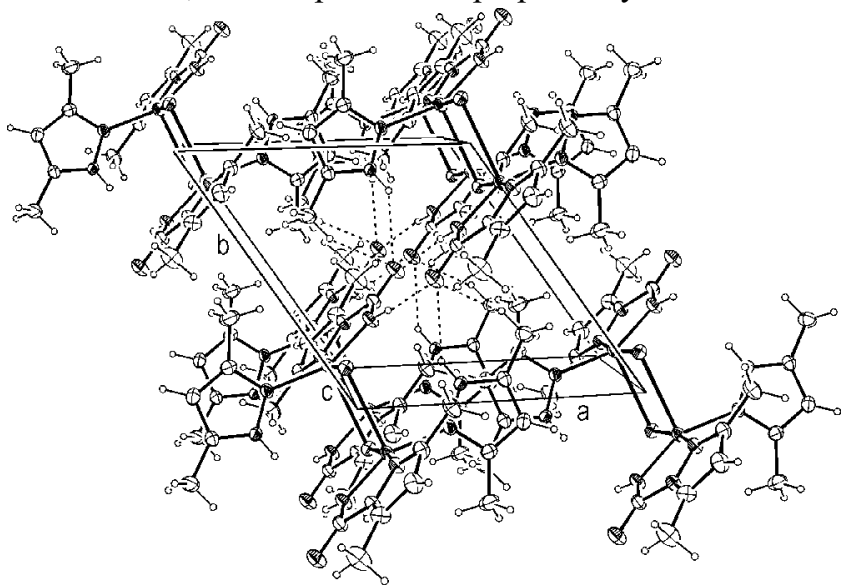


Fig. 2. The equatorial plane of complex $\left[\mathrm{CuBr}\left(\mathrm{HL}^{1}\right)\left(\mathrm{L}^{3}\right)\right]_{2}$ with displaced position of $\mathrm{N} 1$ atom to the $\mathrm{BrCu}$ N3 N5 plane.

Fig. 3. Projection of the crystal packing along crystallographic 'c' axis for $\left[\mathrm{CuBr}\left(\mathrm{HL}^{1}\right)\left(\mathrm{L}^{3}\right)\right]_{2}$ (the dashed lines show the hydrogen bonds).

Table 3

Interatomic bond lengths $\left(\mathrm{A}^{\circ}\right)$ and selected bond angles $(8)$ for $\left[\mathrm{CuBr}\left(\mathrm{HL}^{1}\right)\left(\mathrm{L}^{3}\right)\right]_{2}$

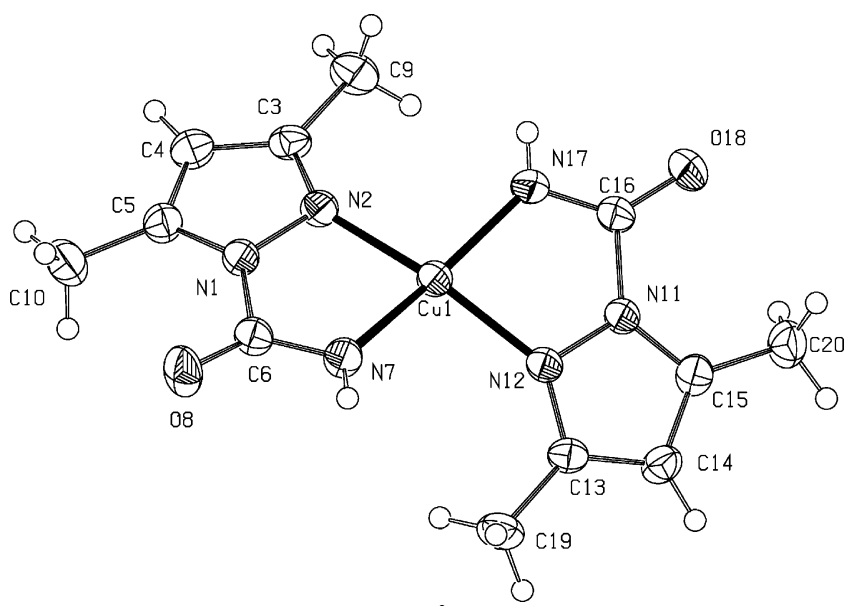

Fig. 4. ORTEP drawing of complex $\mathrm{Cu}\left(\mathrm{L}^{3}\right)_{2}$ with atom numbering scheme.

\begin{tabular}{llll}
\hline Bond lengths & & & \\
\hline $\mathrm{CuN} 5$ & $1.909(8)$ & $\mathrm{C} 3 \mathrm{C} 5$ & $1.501(15)$ \\
$\mathrm{CuN} 1$ & $1.988(8)$ & $\mathrm{N} 3 \mathrm{C} 8$ & $1.328(12)$ \\
$\mathrm{CuN} 3$ & $2.019(8)$ & $\mathrm{N} 3 \mathrm{~N} 4$ & $1.341(11)$ \\
$\mathrm{CuBr}$ & $2.4786(19)$ & $\mathrm{N} 4 \mathrm{C} 6$ & $1.344(13)$ \\
$\mathrm{CuBr} ?$ & $2.770(2)$ & $\mathrm{N} 4 \mathrm{C} 11$ & $1.455(13)$ \\
$\mathrm{N} 1 \mathrm{C} 3$ & $1.342(12)$ & $\mathrm{N} 5 \mathrm{C} 11$ & $1.290(13)$ \\
$\mathrm{N} 1 \mathrm{~N} 2$ & $1.357(10)$ & $\mathrm{C} 6 \mathrm{C} 7$ & $1.343(17)$ \\
$\mathrm{N} 2 \mathrm{C} 1$ & $1.318(12)$ & $\mathrm{C} 6 \mathrm{C} 9$ & $1.504(17)$ \\
$\mathrm{C} 1 \mathrm{C} 2$ & $1.370(14)$ & $\mathrm{C} 7 \mathrm{C} 8$ & $1.437(16)$ \\
$\mathrm{C} 1 \mathrm{C} 4$ & $1.503(15)$ & $\mathrm{C} 8 \mathrm{C} 10$ & $1.468(15)$ \\
$\mathrm{C} 2 \mathrm{C} 3$ & $1.392(15)$ & $\mathrm{OC} 11$ & $1.246(12)$ \\
$\mathrm{Bond}$ angles & & & \\
$\mathrm{N} 5 \mathrm{CuN} 1$ & $154.3(4)$ & $\mathrm{N} 5 \mathrm{CuBr} ?$ & $110.5(3)$ \\
$\mathrm{N} 5 \mathrm{CuN} 3$ & $79.9(4)$ & $\mathrm{N} 1 \mathrm{CuBr} ?$ & $94.6(2)$ \\
$\mathrm{N} 1 \mathrm{CuN} 3$ & $93.9(3)$ & $\mathrm{N} 3 \mathrm{CuBr} ?$ & $93.6(3)$ \\
$\mathrm{N} 5 \mathrm{CuBr}$ & $91.7(3)$ & $\mathrm{BrCuBr} ?$ & $90.08(7)$ \\
$\mathrm{N} 1 \mathrm{CuBr}$ & $93.4(2)$ & $\mathrm{CuBrCu} ?$ \\
$\mathrm{~N} 3 \mathrm{CuBr}$ & $171.5(2)$ & & $89.92(7)$ \\
& & &
\end{tabular}

dimethylpyrazole. By the deprotonation of the ligand the blue b-modification of $\mathrm{Cu}\left(\mathrm{L}^{3}\right)_{2}$ was obtained in a single crystalline form, suitable for an X-ray structure analysis. The deprotonation of the $\mathrm{NH}_{2}$-group (leading to $\mathrm{L}^{3}$ in the complex) is well reflected also by the IR spectrum of the complex, where the respective $\mathrm{NH}$ stretching band has vanished. Additional information provided by IR spectrometry is the unchanged position of the $\mathrm{n}(\mathrm{CO})$ vibrational band upon complex formation indicating that the oxygen atom is not involved in a coordinative bonding with $\mathrm{Cu}$. The IR-spectral data are in accordance with the X-ray analysis. Namely, the oxygen atoms are not involved in co-ordination with the central atom because the $\mathrm{CuO}$ distances for the adjacent molecules are greater than $3.3 \mathrm{~A}^{\circ}[23]$. The coordination is established through the nitrogen atom of the deprotonated carboxamide group and the pyridine nitrogen atom from two ligand molecules.

Both crystalline modifications have a distorted trans square-planar arrangement around the central atom. The ORTEP drawing for the b-modification is presented in Fig. 4. The main difference between the two structures is that the a-modification belongs to monoclinic $\mathrm{P} 2{ }_{1} / \mathrm{c}$ space group with $\mathrm{Z} 4$, while the bmodification to triclinic $\mathrm{P} 1^{-}$space group with $\mathrm{Z} 2$. The interatomic distances and bond angles are given in Table 4 for both a- and b-modifications. The differences are not significant.

In the crystal lattice of the b-modification molecules form N7H7 O8(iii) dimers (Fig. 5), with the following geometrical parameters: $\mathrm{N} 7 \mathrm{H} 70.78 \mathrm{~A}^{\circ}, \mathrm{N} 7 \mathrm{O} 8$ (iii) 3.206(2) $\mathrm{A}^{\circ}, \mathrm{H} 7 \mathrm{O} 8$ (iii) $2.43 \mathrm{~A}^{\circ}, \mathrm{N} 7 \mathrm{H} 7 \mathrm{O} 8$ (iii) 176.78; symmetry code (iii) $\mathrm{x}, \mathrm{y} 1, \mathrm{z}$.

The magnetic moment of the $\mathrm{Cu}\left(\mathrm{L}^{3}\right)_{2}$ and 
$\left[\mathrm{CuBr}\left(\mathrm{HL}^{1}\right)\left(\mathrm{L}^{3}\right)\right]_{2}$ complexes ( $\mathrm{m}_{\text {eff }} 1.80$ and $1.72 \mathrm{~m}_{\mathrm{B}}$, respectively) is characteristic for the $\mathrm{S} 1 / 2$ systems.

The lower $\mathrm{m}_{\text {eff }}$ value for $\left[\mathrm{CuBr}\left(\mathrm{HL}^{1}\right)\left(\mathrm{L}^{3}\right)\right]_{2}$ is in agreement with its bridged structure.

In complexes with $\mathrm{L}^{2}$ and $\mathrm{HL}^{4}, \mathrm{Cu}\left(\mathrm{L}^{2}\right)_{2} \mathrm{Br}_{2}$ and $\mathrm{Cu}\left(\mathrm{HL}^{4}\right)_{2} \mathrm{Br}_{2}$, the pyrazole derivative acts as monodentate ligand through the pyridine ring nitrogen atom. In principle, most of the copper(II) complexes should have a tetrahedral geometry with a magnetic susceptibility of about 2.2 [24]. On this basis ( $\left.\mathrm{m}_{\text {eff }} 2.19\right)$ for the $\mathrm{Cu}\left(\mathrm{L}^{2}\right)_{2} \mathrm{Br}_{2}$ complex a tetrahedral geometry may be assumed, also. For the bis(ligand) complexes of $\mathrm{CuCl}_{2}$ with $\mathrm{HL}^{4}$ a distorted tetrahedral geometry was found by $\mathrm{X}$-ray analysis [10]. As the space requirement of the bromine atoms is larger, for the bromide complex, $\mathrm{Cu}\left(\mathrm{HL}^{4}\right)_{2} \mathrm{Br}$, with the same ligand, a tetrahedral geometry may be proposed.

Copper(II) bromide with $\mathrm{HL}^{5}$ also forms a bis(ligand) complex. Its structure seems to have similar geometry as the analogous copper(II) nitrate complex whose structure was determined by X-ray analysis [25]. In this compound the copper(II) is coordinated endobidentate to the pyridine-type and the $\mathrm{NH}$ nitrogen atoms of the ring and the carboxamidine group, respectively. The nitrate groups are bonded as monodentate species in the axial positions providing thus an octahedral environment around the metal atom. As the complexing ability of the nitrate is low, it is not co-ordinated in solution. Bromides form more readily complexes than nitrates. However, the molar conductivity of the corresponding bromide complex is also high and corresponds to an 1:1 electrolyte. Based on this, for the $\mathrm{CuBr}_{2}\left(\mathrm{HL}^{5}\right)_{2}$ a similar octahedral geometry could be proposed.

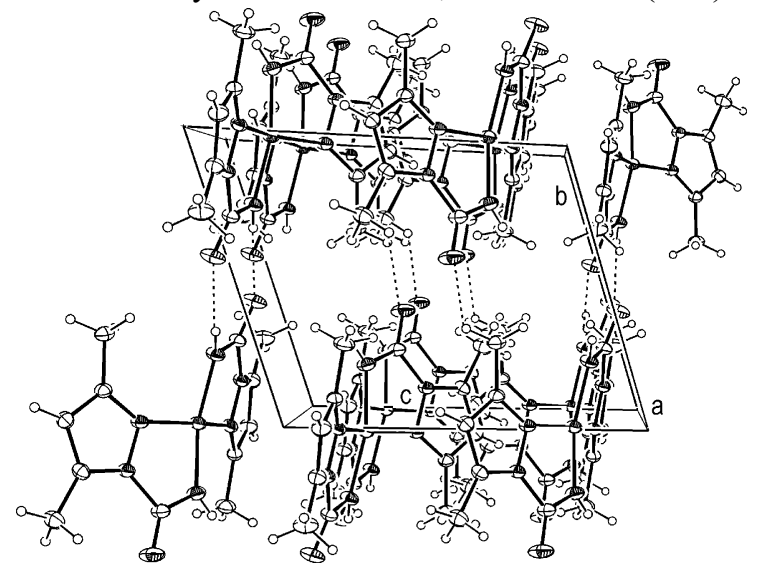

Table 4

Interatomic bond lengths $\left(\mathrm{A}^{\circ}\right)$ and selected bond angles $(8)$ for $\mathrm{b}-\mathrm{Cu}\left(\mathrm{L}^{3}\right)_{2}$ compared to those found in a-modification [22]

\begin{tabular}{|c|c|c|c|c|c|}
\hline Bond lengths & $\mathrm{b}$ & $\mathrm{a}$ & Bond lengths & $\mathrm{b}$ & $\mathrm{a}$ \\
\hline$\overline{\mathrm{Cu} 1 \mathrm{~N} 2}$ & $1.999(1)$ & $1.985(8)$ & $\mathrm{Cu} 1 \mathrm{~N} 12$ & $1.996(1)$ & $1.990(8)$ \\
\hline $\mathrm{Cu} 1 \mathrm{~N} 7$ & $1.924(1)$ & $1.926(8)$ & Cu1 N17 & $1.924(2)$ & $1.908(10)$ \\
\hline N1 N2 & $1.372(2)$ & $1.363(11)$ & N11 N12 & $1.367(2)$ & $1.363(11)$ \\
\hline N1 C5 & $1.356(2)$ & $1.345(13)$ & N11 C15 & $1.357(2)$ & $1.368(13)$ \\
\hline $\mathrm{N} 2 \mathrm{C} 3$ & $1.328(2)$ & $1.352(11)$ & $\mathrm{N} 12 \mathrm{C} 13$ & $1.335(2)$ & $1.316(12)$ \\
\hline $\mathrm{C} 3 \mathrm{C} 4$ & $1.405(3)$ & $1.370(16)$ & $\mathrm{C} 13 \mathrm{C} 14$ & $1.409(2)$ & $1.367(15)$ \\
\hline $\mathrm{C} 4 \mathrm{C} 5$ & $1.376(2)$ & $1.388(14)$ & $\mathrm{C} 14 \mathrm{C} 15$ & $1.379(2)$ & $1.358(13)$ \\
\hline $\mathrm{C} 3 \mathrm{C} 9$ & $1.494(2)$ & $1.461(14)$ & C13C19 & $1.494(2)$ & $1.493(14)$ \\
\hline $\mathrm{C} 5 \mathrm{C} 10$ & $1.488(2)$ & $1.487(15)$ & $\mathrm{C} 15 \mathrm{C} 20$ & $1.484(2)$ & $1.481(16)$ \\
\hline N1 C6 & $1.450(2)$ & $1.465(11)$ & N11 C16 & $1.450(2)$ & $1.432(12)$ \\
\hline C6N7 & $1.315(2)$ & $1.313(14)$ & C16N17 & $1.311(2)$ & $1.306(16)$ \\
\hline $\mathrm{C} 6 \mathrm{O} 8$ & $1.228(2)$ & $1.220(13)$ & $\mathrm{C} 16 \mathrm{O} 18$ & $1.229(2)$ & $1.218(14)$ \\
\hline N2 Cu1 N7 & $81.98(6)$ & $81.5(3)$ & N12 Cu1 N17 & $81.16(6)$ & $81.0(3)$ \\
\hline $\mathrm{N} 2 \mathrm{Cu} 1 \mathrm{~N} 17$ & $100.66(6)$ & $99.8(3)$ & N12 Cu1 N17 & $102.46(6)$ & $99.0(3)$ \\
\hline $\mathrm{N} 2 \mathrm{Cu} 1 \mathrm{~N} 12$ & $157.21(6)$ & $173.5(3)$ & N7 Cu1 N17 & $164.32(8)$ & $168.9(3)$ \\
\hline N1 N2 Cu1 & $109.78(9)$ & $111.0(5)$ & N11 N12 Cu1 & $110.6(1)$ & $110.4(5)$ \\
\hline $\mathrm{C} 3 \mathrm{~N} 2 \mathrm{Cu} 1$ & 141.9(1) & $143.1(6)$ & C13 N12 Cu1 & $142.4(1)$ & $143.4(7)$ \\
\hline $\mathrm{C} 5 \mathrm{~N} 1 \mathrm{~N} 2$ & 111.1(1) & $112.4(7)$ & C15N11 N12 & 111.4(1) & $110.2(7)$ \\
\hline N2 N1 C6 & $117.6(1)$ & $117.6(7)$ & N12 N11 C16 & $117.5(1)$ & $118.0(7)$ \\
\hline $\mathrm{C} 3 \mathrm{~N} 2 \mathrm{~N} 1$ & $106.2(1)$ & $105.8(7)$ & C13 N12 N11 & $106.4(1)$ & $106.2(7)$ \\
\hline N7 C6 N1 & $111.4(1)$ & $110.0(8)$ & N17 C16N11 & $110.8(1)$ & $110.5(9)$ \\
\hline O8 C6N1 & $117.6(2)$ & $117.6(8)$ & O18C16N11 & $117.9(2)$ & $117.9(9)$ \\
\hline
\end{tabular}




\begin{tabular}{|c|c|c|c|c|c|}
\hline C6 N7 Cu1 & $118.3(1)$ & $119.2(6)$ & C16N17 Cu1 & $119.4(1)$ & $119.8(7)$ \\
\hline $\mathrm{N} 2 \mathrm{C} 3 \mathrm{C} 4$ & $109.7(1)$ & $108.6(8)$ & $\mathrm{N} 12 \mathrm{C} 13 \mathrm{C} 14$ & $109.4(1)$ & $110.3(8)$ \\
\hline $\mathrm{N} 2 \mathrm{C} 3 \mathrm{C} 9$ & $123.5(2)$ & $121.6(8)$ & $\mathrm{N} 12 \mathrm{C} 13 \mathrm{C} 19$ & $122.2(2)$ & $122.0(8)$ \\
\hline $\mathrm{N} 1 \mathrm{C} 5 \mathrm{C} 4$ & $106.3(2)$ & 104.3(8) & $\mathrm{N} 11 \mathrm{C} 15 \mathrm{C} 14$ & $106.1(1)$ & $105.6(8)$ \\
\hline $\mathrm{N} 1 \mathrm{C} 5 \mathrm{C} 10$ & $124.9(2)$ & 121.1(8) & N11 C15 C20 & $124.6(2)$ & $124.0(9)$ \\
\hline $\mathrm{C} 3 \mathrm{C} 4 \mathrm{C} 5$ & $106.7(2)$ & $108.9(9)$ & $\mathrm{C} 13 \mathrm{C} 14 \mathrm{C} 15$ & $106.8(2)$ & $107.7(9)$ \\
\hline
\end{tabular}

Fig. 5. Projections of the crystal packing along crystallographic 'a' axis for $\mathrm{Cu}\left(\mathrm{L}^{3}\right)_{2}$.

\subsection{Complex formation reactions}

The influence of the anion on the complex formation was investigated using different copper(II) salts in conjunction with 1carboxamide-3,5-dimethylpyrazole $\left(\mathrm{HL}^{3}\right)$ ligand. We have found that in the reaction of $\mathrm{HL}^{3}$ with $\mathrm{CuBr}_{2}$ a partial decarboxamidation of the ligand takes place, while with $\mathrm{Cu}(\mathrm{OAc})_{2}$ no degradation was observed. In the latter case the Brønsted basicity of the acetate ion in methanol is high enough for the deprotonation of the ligand, replacing thus the voluminous acetate ion and yielding the $\mathrm{Cu}\left(\mathrm{L}^{3}\right)_{2}$ complex. On the other hand, the complex formation with copper(II) chloride leads to a complete decarboxamidation of the ligand [26]. As the Brønsted basicity of both the chloride and bromide ions is too low for the deprotonation of the carboxamide group, the explanation of the complex formation with copper(II) bromide and chloride may be based on Pearson's theory [2729], taking also into account the structural rearrangements and steric factors. In the presence of the hard chloride base a complete decarboxamidation of 1-carboxamide-3,5-dimethylpyrazole takes place, transforming the ligand to 3,5dimethylpyrazole, which allows an intermediate hard hard interaction between the copper(II) and the newly formed ligand. On the other hand, between the relatively small chloride ions and the ligand's methyl substituents the steric repulsion is weak. At the same time the elimination of isocyanic acid is probably promoted by ethanol, forming ethylcarbamate. With copper(II) bromide, decarboxamidation of the ligand occurs, too. However, only one ligand is transformed to 3,5dimethylpyrazole, while the carboxamide group of the other ligand molecule is deprotonated, replacing thus one voluminous bromide ion. Two such molecules are coupled through bromide bridges forming the dimeric $\left[\mathrm{CuBr}\left(\mathrm{HL}^{1}\right)\left(\mathrm{L}^{3}\right)\right]_{2}$ complex with mixed ligands.

\subsection{Thermal decomposition of the compounds}

The thermal decomposition of all the compounds was followed in an air and argon atmosphere with sample masses of about $5 \mathrm{mg}$. The thermal decomposition data in air are given in Table 5. As an example, the TG- and DTG-curves of the decomposition of $\left[\mathrm{CuBr}\left(\mathrm{HL}^{1}\right)\left(\mathrm{L}^{3}\right)\right]_{2}$ and $\mathrm{CuBr}_{2}\left(\mathrm{HL}^{5}\right)_{2}$ in air and argon are presented in Fig.

6 .

All the samples begin to decompose in the temperature range of $400470 \mathrm{~K}$. The lowest thermal stability exhibits the compound with the mixed 3,5-dimethylpyrazole and 1-carboxamide-3,5-dimethylpyrazole ligands, $\left[\mathrm{CuBr}\left(\mathrm{HL}^{1}\right)\left(\mathrm{L}^{3}\right)\right] 2$, which in the context of the mixed softhard interaction can be understandable. The most stable complex is that with 5-amino-4carboxamide-1phenylpyrazole, $\mathrm{CuBr}_{2}\left(\mathrm{~L}^{2}\right)_{2}$, presumably because of the $\mathrm{n} 0 \mathrm{p}$ transition between the unshared electrons of the pyrazole nitrogen and phenyl nucleus.

The decomposition of $\mathrm{Cu}\left(\mathrm{L}^{3}\right)_{2}$ in air results in an unstable intermediate around $470 \mathrm{~K}$. In the mass spectrum recorded at the beginning of the decomposition, the molecular peak of 3,5-dimethylpyrazole, accompanied by the peaks of its fragments, was observed. This was followed by the peak of $\mathrm{H}_{2}$ evolution. The intermediate was isolated and investigated by IR spectrometry. The characteristic changes in the IR spectrum include the disappearance of the $\mathrm{n}(\mathrm{NH})$ vibrational band at $3302 \mathrm{~cm}^{1}$ and the rise of new bands at 2241 and $2170 \mathrm{~cm}^{1}$. These latter bands can be assigned to coupled stretching vibrations of two isocyanate groups within a molecule. Another characteristic new band appears at $3122 \mathrm{~cm}^{1}$ assigned to $\mathrm{CH}_{2}$

Table 5

Thermal decomposition data in air 


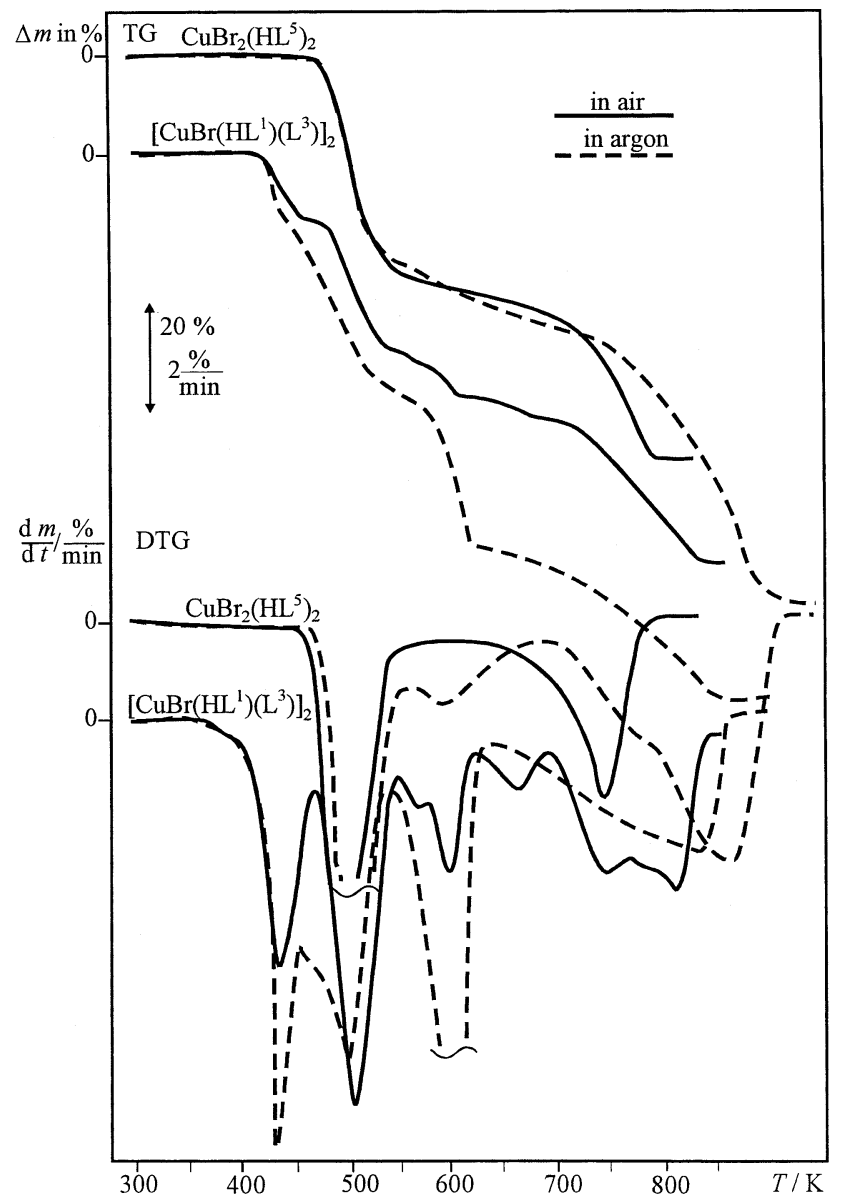

Fig. 6. TG-DTG curves for the $\mathrm{CuBr}_{2}\left(\mathrm{HL}^{5}\right)_{2}$ and $\left[\mathrm{CuBr}\left(\mathrm{HL}^{1}\right) \mathrm{L}^{3}\right]_{2}$ in air and in argon.

\begin{tabular}{|c|c|c|c|c|c|c|}
\hline \multirow[t]{2}{*}{ Compound } & \multirow[t]{2}{*}{ Temperature Range in $\mathrm{K}$} & \multicolumn{2}{|c|}{ Mass loss in $\%$} & \multirow[t]{2}{*}{ Temperature in $\mathrm{K}$} & \multicolumn{2}{|c|}{ Residue (\%) } \\
\hline & & $\begin{array}{l}\text { Found } \\
\text { (depa }\end{array}$ & $\begin{array}{l}\text { Calc. } \\
\text { p) }\end{array}$ & & Found & Calc. \\
\hline \multirow[t]{2}{*}[\mathrm{CuBr}(\mathrm{HL}^{1})(\mathrm{L}^{3})]{$_{2}$} & 400467 & 12.6 & 12.72 & 830 & 29.3 & 29.52 \\
\hline & & \multicolumn{2}{|c|}{$(-3,5-\mathrm{DMP})$} & $\mathrm{CuOCuBr}$ & $(1: 1)$ & \\
\hline \multirow[t]{2}{*}{$\mathrm{CuBr}_{2}\left(\mathrm{~L}^{2}\right)_{2}$} & 470680 & 26.7 & 24.57 & 920 & 27.5 & \\
\hline & & \multicolumn{2}{|c|}{$(-2 \mathrm{Ph})$} & $?$ & & \\
\hline \multirow[t]{2}{*}{$\mathrm{Cu}\left(\mathrm{L}^{3}\right)_{2}$} & 425485 & 30.0 & 28.88 & 690 & 21.8 & 23.40 \\
\hline & & \multicolumn{2}{|c|}{$\left(\mathrm{C}_{5} \mathrm{H}_{10} \mathrm{~N}_{2}\right)$} & $\mathrm{CuO}$ & & \\
\hline $\mathrm{CuBr}_{2}\left(\mathrm{HL}^{4}\right)_{2}$ & 430530 & 8.0 & 8.57 & 930 & 19.6 & 22.22 \\
\hline
\end{tabular}


$\mathrm{CuBr}_{2}\left(\mathrm{HL}^{5}\right)_{2}$

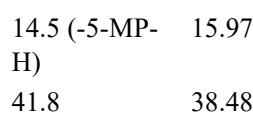

$\mathrm{CuOCuBr}$

alitative analysis.

stretching vibrations. The spectrum contains additionally the bands of the methylpyrazole ligand, too. This is the consequence of the low stability of the intermediate, viz., the decomposition of the starting compound was not finished yet when the next decomposition step started. The elemental analysis (Found (\%) C, 36.55; H, 3.7; N, 20.04, Required (\%): C, 34.78; H. 2,50; N. 23,18) and mass loss data up to $500 \mathrm{~K}$ (Found (\%) 30.0; Required (\%): 28.88) as well as the IR results indicate an elimination process presented in Scheme 1. We note that an analogous isothiocyanate intermediate has been suggested for the formation mechanism of $\left[\mathrm{CuCl}_{2}\left(\mathrm{HL}^{1}\right)\right]_{2}$ and $\mathrm{CuCl}_{2}\left(\mathrm{HL}^{1}\right)_{2}$ complexes from 1carboxamide-3,5dimethylpyrazole [26].

The thermal decomposition of the pyrazole complexes is usually independent of purge gas up to $500600 \mathrm{~K}$. Above this temperature the degradation in argon slows down and in most cases is not finished up to $1100 \mathrm{~K}$, as is the case with $\mathrm{CuBr}_{2}\left(\mathrm{~L}^{2}\right)_{2}$, $\mathrm{Cu}\left(\mathrm{L}^{3}\right)_{2}$ and $\mathrm{CuBr}_{2}\left(\mathrm{HL}^{4}\right)_{2}$ complexes. However, an interesting phenomenon was observed at the decomposition of the $\left[\mathrm{CuBr}\left(\mathrm{HL}^{1}\right)\left(\mathrm{L}^{3}\right)\right]_{2}$ and $\mathrm{CuBr}_{2}\left(\mathrm{HL}^{5}\right)_{2}$ complexes: in argon above $900 \mathrm{~K}$ no residue was obtained. Unfortunately, at the end of the decomposition, by mass spectrometry we could not detect the evolved fragments, due to too high decomposition temperature. The different thermal decomposition pattern of the compounds in air and argon atmospheres may be explained by the increased basicity and acidity of the remaining components with increasing temperature [30]. Thus, in the $\mathrm{CuBr}_{2}\left(\mathrm{HL}^{5}\right)_{2}$ and $\left[\mathrm{CuBr}\left(\mathrm{HL}^{1}\right)\left(\mathrm{L}^{3}\right)\right]_{2}$ complexes the covalency of the bonds is strengthened to the extent which allows a complete evaporation of the remaining parts of the molecule in argon.

The decomposition of the compounds starts with an endothermic reaction which is usually accompanied by the melting of the sample. The next step is an exothermic process except for $\mathrm{CuBr}_{2}\left(\mathrm{HL}^{5}\right)_{2}$ and $\left[\mathrm{CuBr}\left(\mathrm{HL}^{1}\right)\left(\mathrm{L}^{3}\right)\right]_{2}$ complexes which is in agreement with the different thermal behavior of these compounds in argon.

\section{Supplementary material}

A full list of crystal data and refinement have been deposited at the Cambridge Crystallographic Data Centre, CCDC Nos. 179602 and 179603 for $\mathrm{Cu}\left(\mathrm{L}^{3}\right)_{2}$ and $\left[\mathrm{CuBr}\left(\mathrm{HL}^{1}\right)\left(\mathrm{L}^{3}\right)\right]_{2}$, respectively. Copies of this information may be obtained free of charge from The Director, CCDC, 12 Union Road, Cambridge, CB2 1EZ, UK (fax: 44-1223-336-033; e-mail: deposit@ccdc.cam.ac.uk or www: http://www.ccdc.cam.ac.uk).

\section{Acknowledgements}

The authors (K. Me'sza'ros Sze'cse'nyi) would like to thank the Domus Hungarica Scientiarum Artiumque Foundation for their support and the Hungarian National Scientific Research Foundation (OTKA, T038189, A. Kova'cs). The work was financed in part by the Ministry for Science and Technology of the Republic of Serbia. 


\section{References}

[1] S.R. Lukic', V.M. Leovac, A.F. Petrovic', S.J. Skuban, V.I. C`es`ljevic', M.M Garic', Synth. React. Inorg. Met. Org. Chem. 32 (2002) 873.

[2] (a) W.G. Haanstra, Ph.D. Thesis, Leiden University, Leiden, The Netherlands, 1991;

(b) W.G. Haanstra, W.A.J.W. van der Donk, W.L. Driessen, J. Reedijk, J.S. Wood, M.G.B. Drew, J. Chem. Soc., Dalton (1990) 3123.

[3] S. Trofimenko, in: S.J. Lippard (Ed.), Progress in Inorganic Chemistry, vol. 34, Wiley, New York, 1986, p. 115.

[4] N.T. Sorrel, Tetrahedron 45 (1989) 3.

[5] S. Trofimenko, Chem. Rev. 93 (1993) 943.

[6] R. Mukherjee, Coord. Chem. Rev. 203 (2000) 151.

[7] K. Me'sza'ros Sze'cse'nyi, E.Z. Iveges`, V.M. Leovac, L.S. Vojinovic, A. Kova'cs, G. Pokol, J. Madara'sz, Z`.K. Jacimovic, Thermochim. Acta 316 (1998) 79.

[8] K. Me'sza'ros Sze'cse'nyi, E.Z. Iveges`, V.M. Leovac, A. Kova'cs, G. Pokol, Z`.K Jac'imovic', J. Therm. Anal. Cal. 56 (1999) 493.

[9] K. Me'sza'ros Sze'cse'nyi, V.M. Leovac, Z.K. Jacimovic, V.I. C`es`ljevic, A. Kova'cs, G. Pokol, J. Therm. Anal. Cal. 63 (2001) 723.

[10] A. Hergold-Brundic', B. Kaitner, B. Kamenar, V.M. Leovac, E.Z. Ivegeš , N. Juranic', Inorg. Chim. Acta 188 (1991) 151.

[11] M.N. Burnett, C.K. Johnson, ORTEPIII, Report ORNL-6895. Oak Ridge National Laboratory, Oak Ridge, TN, 1996.

[12] A. Szabo', V.I. C`es`ljevic', A. Kova'cs, Chem. Phys. 270 (2001) 67. [13] G. Socrates, Infrared Characteristic Group Frequencies. Tables and Charts, 2nd ed., Wiley, New York, 1994.

[14] K. Nakamoto, Infrared and Raman Spectra of Inorganic and Coordination Compounds, in: Applications in Co-ordination, Organometallic and Bioinorganic Chemistry, Part B, 5th ed., Wiley, New York, 1997.

[15] Enraf-Nonius. CAD-4 Software. Version 5. Enraf-Nonius, Delft, The Netherlands, 1989.

[16] C.K. Fair, MolEN, An Interactive Intelligent System for Crystal Structure Analysis, Enraf-Nonius, Delft, The Netherlands, 1990.

[17] A.C. North, D.C. Philips, F. Mathews, Acta Crystallogr., A 24 (1968) 350.

[18] (a) A.L. Spek, Acta Crystallogr., A 46 (1990) C34; (b) A.L. Spek, PLATon, A Multipurpose Crystallographic Tool, Utrecht University, Utrecht, The Netherlands, 1998.

[19] G.M. Sheldrick, shelXs86, Program for the Solution of Crystal Structures, University of Go"ttingen, Go"ttingen, Germany, 1985.

[20] G.M. Sheldrick, sHELXL97, Program for the Refinement of Crystal Structures, University of Go“ttingen, Go“ttingen, Germany, 1997.

[21] W.J. Geary, Coord. Chem. Rev. 7 (1971) 81.

[22] F. Valach, J. Kohout, M. Dunaj-Jurco, M. Hvastijova', J. Gazo, J. Chem. Soc., Dalton (1979) 1867.

[23] J. Gazo, I.B. Bersuker, J. Garaj, M. Kabesova', J. Kohout, H. Langfelderova', M. Melnik, M. Sera'tor, F. Valach, Coord. Chem. Rev. 19 (1976) 253.

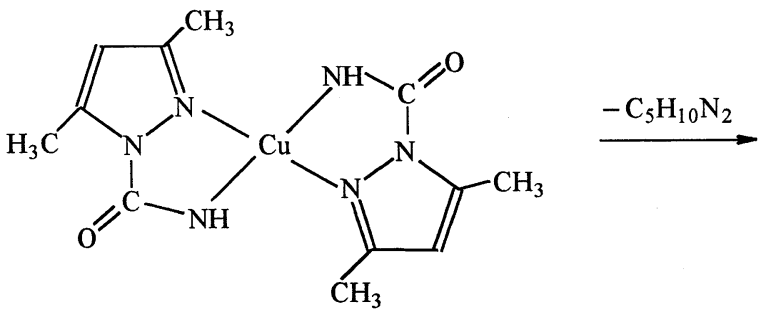

$\mathrm{Cu}\left(\mathrm{L}^{3}\right)_{2}$

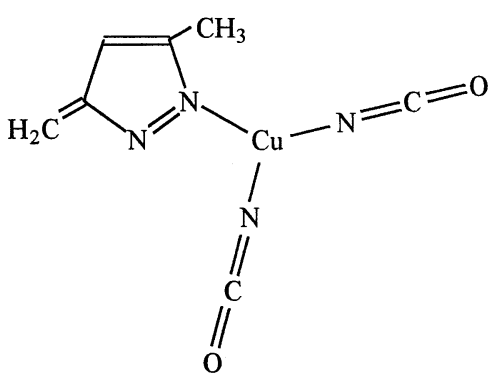

Scheme 1.

[24] A.B. Neinding, Magnetochemistry of Transition Metal Complexes, Results in Sciences (Series Chemistry), Moscow (1970) 205 (in Russian).

[25] Z.K. Jacimovic, Ph.D. Thesis, University of Novi Sad, Faculty of Sciences and Mathematics, Yugoslavia (1998) 76.

[26] K. Me'sza'rossze'cse'nyi, Z.K. Jacimovic, V.M. Leovac, V.I. C`es`ljevic, A. Kova'cs, G. Pokol, J. Therm. Anal. Cal. 66 (2001) 573.

[27] R.G. Pearson, J. Am. Chem. Soc. 85 (1963) 3533.

[28] R.G. Pearson, Science 151 (1966) 172.

[29] R.G. Pearson, J. Songstad, J. Am. Chem. Soc. 89 (1967) 1827.

[30] (a) L. Erdey, Period Politech Chem. 1 (1957) 91; (b) L. Erdey, S. Gal, Talanta 10 (1963) 23. 